\title{
Fine mapping of a Phytophthora-resistance locus RpsGZ in soybean using genotyping- by-sequencing
}

Bingzhi Jiang ${ }^{1,2,3 \dagger}$, Yanbo Cheng ${ }^{1,2 \dagger}$, Zhandong Cai ${ }^{1,2}$, Mu Li $^{1,2}$, Ze Jiang ${ }^{1,2}$, Ruirui Ma ${ }^{1,2}$, Yeshan Yuan ${ }^{1,2}$, Qiuju Xia ${ }^{4}$ and Hai Nian ${ }^{1,2^{*}}$ (D)

\begin{abstract}
Background: Phytophthora root rot (PRR) caused by Phytophthora sojae (P. sojae) is one of the most serious limitations to soybean production worldwide. The identification of resistance gene(s) and their incorporation into elite varieties is an effective approach for breeding to prevent soybean from being harmed by this disease. A valuable mapping population of $228 \mathrm{~F}_{8: 11}$ recombinant inbred lines (RILs) derived from a cross of the resistant cultivar Guizao1 and the susceptible cultivar BRSMG68 and a high-density genetic linkage map with an average distance of 0.81 centimorgans (CM) between adjacent bin markers in this population were used to map and explore candidate gene(s).

Results: PRR resistance in Guizao1 was found to be controlled by a single Mendelian locus and was finely mapped to a 367.371-kb genomic region on chromosome 3 harbouring 19 genes, including 7 disease resistance (R)-like genes, in the reference Willliams 82 genome. Quantitative real-time PCR assays of possible candidate genes revealed that Glyma.03 g05300 was likely involved in PRR resistance.

Conclusions: These findings from the fine mapping of a novel Rps locus will serve as a basis for the cloning and transfer of resistance genes in soybean and the breeding of $P$. sojae-resistant soybean cultivars through markerassisted selection.
\end{abstract}

Keywords: Soybean, Phytophthora root rot, Resistance locus, SNP, Fine mapping

\section{Background}

Phytophthora root rot (PRR) caused by Phytophthora sojae is one of the most important soil-borne diseases in many soybean-producing regions of the world and causes significant soybean production losses [1].

\footnotetext{
* Correspondence: hnian@scau.edu.cn

${ }^{\dagger}$ Bingzhi Jiang and Yanbo Cheng contributed equally to this work.

'The State Key Laboratory for Conservation and Utilization of Subtropical Agro-bioresources, South China Agricultural University, Guangzhou,

Guangdong 510642, People's Republic of China

${ }^{2}$ The Key Laboratory of Plant Molecular Breeding of Guangdong Province, College of Agriculture, South China Agricultural University, Guangzhou, Guangdong 510642, People's Republic of China

Full list of author information is available at the end of the article
}

Soybean resistance to $P$. sojae is mainly controlled by two mechanisms, involving complete or partial resistance genes $[2,3]$. The former type of resistance is related to a single dominant resistance gene [4-19], with $P$. sojae interacting with Rps genes in a gene-for-gene system preventing disease development in plants [20], while the latter involves multiple genes and limits damage to the plant $[3,21]$.

To our knowledge, more than 33 Rps genes/alleles on 9 different soybean chromosomes have been identified and mapped, among which Rps1 (including five alleles, Rps1a, Rps1b, Rps1c, Rps1d and Rps1k), Rps7, Rps9, RpsYu25, RpsYD29, RpsWY, RpsUN1, RpsHN, RpsHC18,

(c) The Author(s). 2020 Open Access This article is licensed under a Creative Commons Attribution 4.0 International License, which permits use, sharing, adaptation, distribution and reproduction in any medium or format, as long as you give appropriate credit to the original author(s) and the source, provide a link to the Creative Commons licence, and indicate if changes were made. The images or other third party material in this article are included in the article's Creative Commons licence, unless indicated otherwise in a credit line to the material. If material is not included in the article's Creative Commons licence and your intended use is not permitted by statutory regulation or exceeds the permitted use, you will need to obtain permission directly from the copyright holder. To view a copy of this licence, visit http://creativecommons.org/licenses/by/4.0/ The Creative Commons Public Domain Dedication waiver (http://creativecommons.org/publicdomain/zero/1.0/) applies to the data made available in this article, unless otherwise stated in a credit line to the data. 
RpsQ, Rps $X$ and an unnamed Rps gene in Wascshiroge and E00003 soybean were mapped to chromosome 3 [7, 9, 10, 13, 14, 22-31]. Rps3 (including three alleles, Rps3a, Rps3b and Rps3c) and RpsSN10 were mapped to chromosome 13, which is linked with Rps8 [6, 22, 32, 33]. Rps 2 and RpsUN2 were found on chromosome 16 [22, 28]. Additionally, Rps4, Rps5, Rps6, Rps 12 and RpsJS are located on chromosome 18 [16, 19, 22, 34, 35], and RpsYB30, RpsZS18, RpsSu, Rps10 and Rps11 are located on chromosomes 19, 2, 10, 17 and 7 , respectively $[8,11$, $18,36,37]$. Among the identified Rps genes on chromosome 3, Rps $1 \mathrm{k}$ was mapped to a $125-\mathrm{kb}$ region and cloned and was found to show an NBS-LRR structure that is typical of a resistance protein [24, 38]. RpsYD29 was mapped to a $204.8-\mathrm{kb}$ region, and two nucleotidebinding site and leucine-rich repeat (NBS-LRR)-type genes, Glyma03g04030.1 and Glyma03g04080.1, were identified [27]. Moreover, $R p s Q$ was finely mapped to a 118-kb region [13].

Recently, with the progress of massively parallel DNA sequencing platforms, whole-genome sequencing (WGS) has become the primary strategy for next-generation sequencing (NGS) for SNP discovery and genotyping in large populations. These methods include resequencing, genotyping by-sequencing (GBS) [39], specific length amplified fragment sequencing (SLAF-seq) [40], restriction site-associated DNA tag sequencing (RAD-seq) [41], and 2b-RAD [42]. NGS technologies have been widely utilized in soybean, wheat, sunflower and other crops to develop SNP markers and map genes/QTLs [11, 43-47]. The dominant soybean Phytophthora root rot resistance gene $R p s W Y$ was mapped using a high-density soybean genetic map comprising 3469 recombination bin markers using RAD-seq technology in $196 \mathrm{~F}_{7: 8}$ RILs [31].

In this study, we found that the cultivar Guizaol presented broad-spectrum resistance and may carry $R p s$ genes or alleles. The objectives of our project were to characterize the inheritance of the Rps gene(s) and finely map the candidate gene(s) of the resistant cv. Guizao1 using a high-density genetic linkage map comprising 3748 recombination bin markers using RAD-seq technology in $228 \mathrm{~F}_{8}$ RILs derived from a cross of Guizao1 $\times$ BRSMG68.

\section{Results}

\section{Phenotype reaction of the parents to $P$. sojae isolates}

To investigate the phenotypes of Guizaol and BRSMG68, six isolates of $P$. sojae were used to test the reactions of the genetically different soybean varieties (Table 1). The inoculation results showed that BRSMG68 showed the same SSSSSS reaction as Williams, indicating that BRSMG68 did not contain known disease resistance genes. Guizao1 (RSRSSS), Chapman (RRRRSR), L85-3059 (RSRSSR) and Harosoy (RSSSSS)
Table 1 Differential reactions of soybean hosts and cultivars to strains of $P$. sojae

\begin{tabular}{|c|c|c|c|c|c|c|c|}
\hline \multirow[t]{2}{*}{ Cultivar } & \multirow[t]{2}{*}{ Rps } & \multicolumn{6}{|c|}{ Phytophthora sojae strains } \\
\hline & & PNJ4 & Pm28 & PNJ1 & PNJ3 & Pm14 & P6497 \\
\hline Guizao1 & & $R$ & $S$ & $\mathrm{R}$ & $\mathrm{s}$ & $\mathrm{S}$ & $S$ \\
\hline BRSMG68 & & S & $S$ & $S$ & S & $S$ & S \\
\hline Harlon & $1 a$ & S & $S$ & $\mathrm{R}$ & S & $\mathrm{S}$ & $\mathrm{R}$ \\
\hline Harosoy $13 \mathrm{XX}$ & 16 & S & S & $\mathrm{R}$ & S & S & S \\
\hline Williams79 & $1 c$ & S & $S$ & $\mathrm{R}$ & S & S & $\mathrm{R}$ \\
\hline PI103091 & $1 d$ & S & S & $S$ & S & S & $\mathrm{R}$ \\
\hline Williams82 & $1 k$ & S & S & $\mathrm{R}$ & $\mathrm{S}$ & $S$ & $\mathrm{R}$ \\
\hline L76-988 & 2 & S & S & $S$ & $S$ & S & S \\
\hline Chapman & $3 a$ & $\mathrm{R}$ & $\mathrm{R}$ & $\mathrm{R}$ & $\mathrm{R}$ & $S$ & $\mathrm{R}$ \\
\hline PRX146-36 & $3 b$ & S & $S$ & $S$ & S & $\mathrm{R}$ & $\mathrm{R}$ \\
\hline PRX145-48 & $3 c$ & S & $\mathrm{S}$ & $S$ & S & $\mathrm{S}$ & S \\
\hline L85-2352 & 4 & S & $\mathrm{R}$ & $S$ & $\mathrm{R}$ & S & $\mathrm{R}$ \\
\hline L85-3059 & 5 & $\mathrm{R}$ & $\mathrm{S}$ & $\mathrm{R}$ & S & S & $\mathrm{R}$ \\
\hline Harosoy62XX & 6 & S & $S$ & $S$ & $\mathrm{R}$ & $S$ & $\mathrm{R}$ \\
\hline Harosoy & 7 & $\mathrm{R}$ & S & $S$ & $\mathrm{~S}$ & $\mathrm{~S}$ & $S$ \\
\hline Williams & rps & S & S & $\mathrm{S}$ & S & S & $S$ \\
\hline
\end{tabular}

were PRR resistant to the $P$. sojae PNJ4 strain, while other varieties were PRR susceptible to the PNJ4 strain (Table 1). Furthermore, Guizaol also PRR resistant to the PNJ1 strain but PRR susceptible to the Pm28, PNJ3, Pm14, and P6497 strains, which was different from what was observed for Chapman, L85-3059 and Harosoy. The inoculation results suggest that Guizaol may contain a novel Rps gene or resistance locus.

\section{Genetic analysis of resistance to $P$. sojae PNJ4}

Among the $228 \mathrm{~F}_{8: 11}$ RILs obtained from the cross of Guizao1 $\times$ BRSMG68, 113 RILs were homozygous resistant, and 115 RILs were homozygous susceptible, with the segregation ratio fitting with the Mendelian genotypic ratio of $1 \mathrm{R}: 1 \mathrm{~S}\left(\mathrm{X}^{2}=0.004, P=0.95\right.$, Table 2$)$. These results indicated that PRR resistance in Guizao1 was controlled by a single locus, which we temporarily designated as RpsGZ.

Fine mapping of RpsGZ by high-throughput genome-wide resequencing

Based on the high-density map constructed with bins as markers and the use of CIM with WinQTLCart for PRR resistance locus localization, only one PRR resistance locus was detected on chromosome 3 in Guizao1 (Fig. 1), with a log-likelihood (LOD) value of 88.28 , which explained $81.75 \%$ of the phenotypic variance. In the highdensity linkage map (Additional file: Fig. S1), RpsGZ was placed in bin31 according to the results for six recombinant monoclonal lines (Fig. 2). This placed RpsGZ in a 
Table 2 Segregation analysis of resistance to P. sojae PNJ4 in F 8:11 (Guizao1 × BRSMG68)

\begin{tabular}{llllll}
\hline Cross or Parent $^{\mathrm{a}}$ & \multicolumn{2}{l}{ Total no. of plants/lines } & & \multicolumn{2}{l}{ Expected ratio and goodness of fit } \\
\cline { 2 - 3 } & Resistance & Susceptibility & & Expected ratio & $X^{2}$ \\
\hline BRSMG68 & 0 & 180 & & \\
Guizao1 & 180 & 115 & $1: 1$ & 0.004 \\
F8:11(Guizao1 $\times$ BRSMG68) & 113 & 0 & 0.95 \\
\hline
\end{tabular}

() BRSMG68 was PRR-susceptible cultivars to PNJ4 strain, and Guizao1 was PRR-resistant to PNJ4 strain

region between 4,003,401 and 4,370,772 bp in GlymaWm82.a2.v1, covering appropriately $367,371 \mathrm{bp}$. A BLAST search showed 19 annotated genes based on this assembly (Table 3; http://www.soybase.org). The putative functions of these predicted genes were annotated via BLAST searches against the TAIR protein datasets and the Phytozome Genomics Resource (https://phytozome. jgi.doe.gov/pz/portal.html), and five genes (Glyma.03G034400, Glyma.03G034500, Glyma.03G034800, Glyma.03G034900 and Glyma.03G035300) were found to contain nucleotide-binding site (NBS)-leucine-rich repeat (LRR) domains, which are important domains of plant disease resistance genes. Glyma.03G035900 is a membrane attack complex/perforin (MACPF) domainencoding gene, and the MACPF proteins play a role in immunity (http://pfam.xfam.org). Glyma.03G036000 encodes a serine/threonine protein kinase that plays an important role in signalling and plant defence activities. Therefore, these seven R-like genes were most likely the candidate genes of RpsGZ.

\section{Gene ontology (GO) enrichment analysis of the candidate genes}

The AgriGO toolkit was used to perform gene ontology (GO) analysis [48, 49]. Among the 19 genes in the region close to RpsGZ detected in this study, 9 genes were found to show at least one GO annotation (Additional file: Fig. S2, Table S1 and Table S2). These genes were predicted to be involved in biological processes and molecular functions including protein kinase activity,

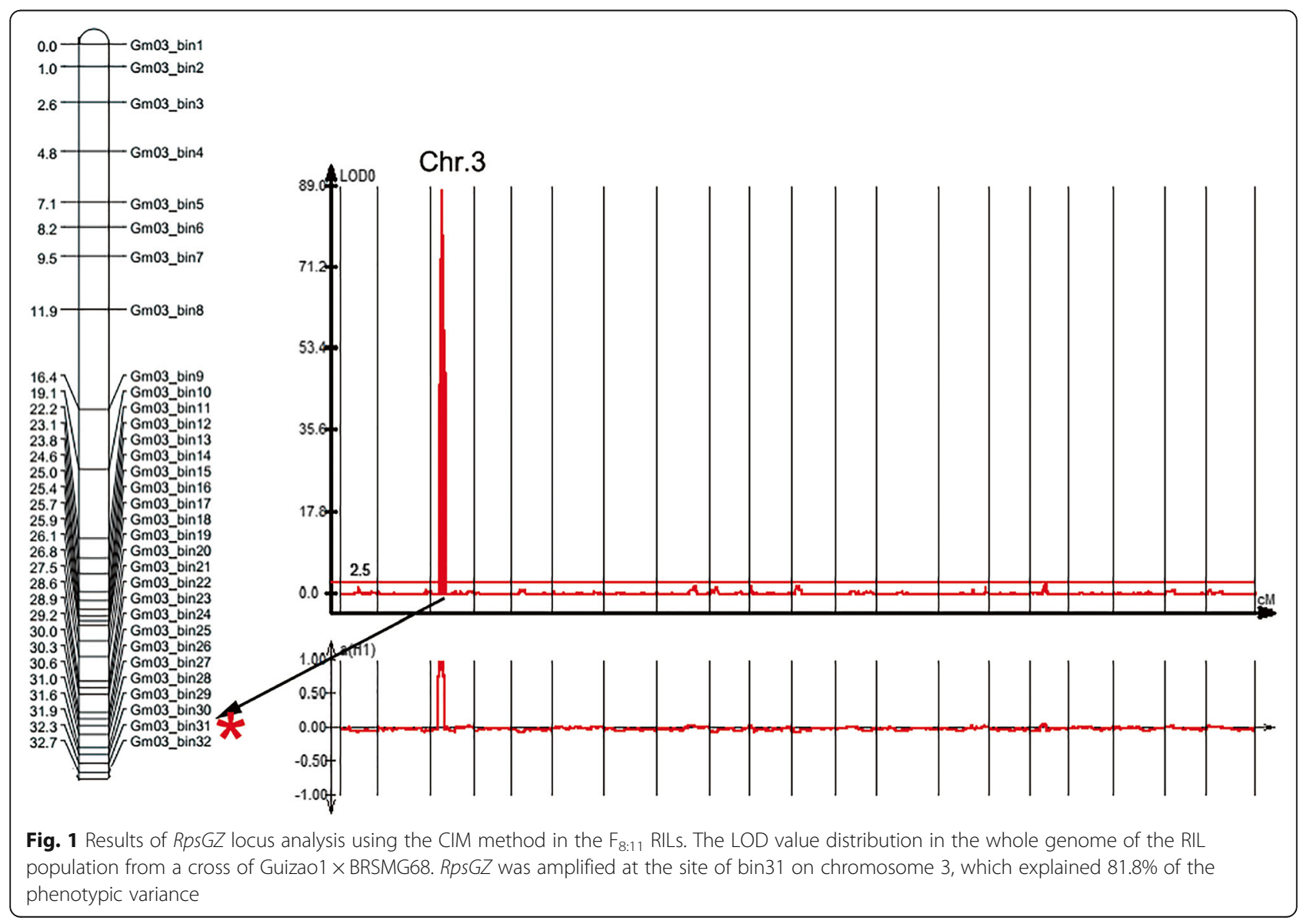




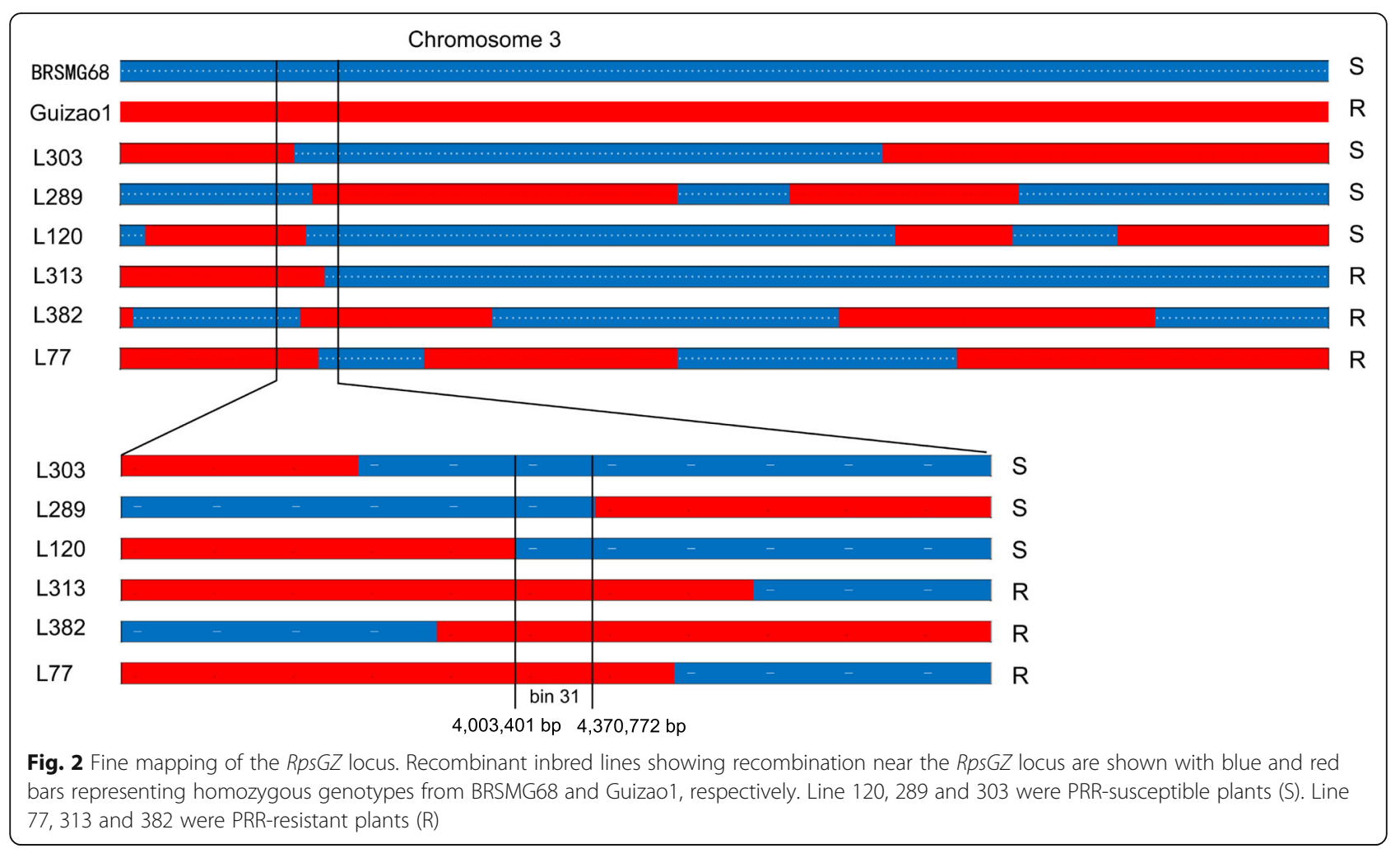

Table 3 Annotations of the candidate genes in the Rps $G Z$ region on chromosome 3

\begin{tabular}{llll}
\hline No & Gene name & Annotation & Ortholog $^{\text {b }}$ \\
\hline 1 & Glyma.03G034400 & Disease resistance protein (NBS-LRR class), putative ${ }^{c}$ & AT3G14470.1 \\
2 & Glyma.03G034500 & Disease resistance protein (NBS-LRR class), putative & AT3G14470.1 \\
3 & Glyma.03G034600 & No items to show & AT1G62130.1 \\
4 & Glyma.03G034700 & No items to show & AT2G01050.1 \\
5 & Glyma.03G034800 & Disease resistance protein (NBS-LRR class), putative & AT3G14470.1 \\
6 & Glyma.03G034900 & Disease resistance protein (NBS-LRR class), putative & AT3G14470.1 \\
7 & Glyma.03G035000 & Domain of unknown function DUF223 & AT2G05642.1 \\
8 & Glyma.03G035100 & PIF1-like helicase & AT3G51690.1 \\
9 & Glyma.03G035200 & CW-type Zinc Finger; B3 DNA binding domain & AT4G32010.1 \\
10 & Glyma.03G035300 & Disease resistance protein (NBS-LRR class), putative. Protein tyrosine kinase & AT3G08760.1 \\
11 & Glyma.03G035400 & PPR repeat & AT3G42630.1 \\
12 & Glyma.03G035500 & Plant mobile domain & AT2G04865.1 \\
13 & Glyma.03G035600 & Protease inhibitor/seed storage/LTP family & AT3G08770.1 \\
14 & Glyma.03G035700 & No items to show & AT5G59310.1 \\
15 & Glyma.03G035800 & Pollen allergen; Rare lipoprotein A (RlpA)-like double-psi beta-barrel & AT5G05290.1 \\
16 & Glyma.03G035900 & Membrane attack complex/Perforin domain & AT1G29690.1 \\
17 & Glyma.03G036000 & Protein tyrosine kinase; Serine-threonine protein kinase & AT5G01850.1 \\
18 & Glyma.03G036100 & No items to show & AT2G38510.1 \\
\hline 19 & Glyma.03G036200 & Multidrug resistance protein &
\end{tabular}

(') Glyma ID from the Williams 82 soybean reference genome Wm82.a2.v1 (http://soybase.org)

(b) Accession number of Arabidopsis orthologs were obtained from the Arabidopsis Information Resource (TAIR10, http://www.arabidopsis.org/)

(c) NBS-LRR: Nucleotide-binding site (NBS) -leucine-rich repeat (LRR) domains 
protein amino acid phosphorylation, ribonucleotide binding, cellular processes, ADP binding, and nucleoside binding. In the molecular function category, the GO terms "adenyl nucleotide binding" "purine ribonucleotide binding" and "adenyl ribonucleotide binding" were significantly enriched (Fig. S2). Among the GO terms, both Glyma.03G035300 and Glyma.03G036000 were associated with the term "GO:0006468 protein amino acid phosphorylation". Protein phosphorylation is a ubiquitous mechanism for modulating protein function [50] and plays a role in defence mechanisms against disease.

\section{Expression profiling for the identification of resistance genes}

To confirm which genes were induced under infection with $P$. sojae, the expression patterns of 7 R-like genes were examined in Guizao1 and BRSMG68 using qRTPCR analysis (Fig. 3). The expression levels of four genes (i.e., Glyma.03G034400, Glyma.03G034500, Glyma.03G034900 and Glyma.03G035900) were upregulated at most time points after infection in Guizao1 and BRSMG68. However, the other genes (Glyma.03 g034800, Glyma.03g035300 and Glyma.03 g036000) were downregulated at 3, 6, 24 and $36 \mathrm{~h}$ after treatment in Guizao1 and BRSMG68.

The expression of Glyma.03G034400, Glyma.03G034500, Glyma.03G034900 and Glyma.03 g036000 in the susceptible cv. BRSMG68 was higher than in the resistant cv. Guizaol at most time points after infection. The expression of Glyma.03G035300 in Guizao1 was higher than that in BRSMG68 at 3, 6, and $12 \mathrm{~h}$ after treatment, reaching a maximum expression increase of approximately 2.1 -fold at $12 \mathrm{~h}$ after treatment, followed by a decrease from 24 to $72 \mathrm{~h}$ after treatment. A similar expression pattern was observed for the Glyma.03G034800 gene, with a relatively low expression level. These results showed that the Glyma.03G035300 gene may be involved in disease-defence mechanisms.

\section{Discussion}

Soybean is one of the most important crops in the world. There are a large number of soybean accessions in China, among which many PRR-resistant cultivars/ lines were identified in a previous study $[10,13,14,51-$ 55]. In the present study, the Guizaol cultivar was PRR resistant to $P$. sojae PNJ4 and PNJ1, thus differing from the other soybean cultivars tested (Table 1). Genetic

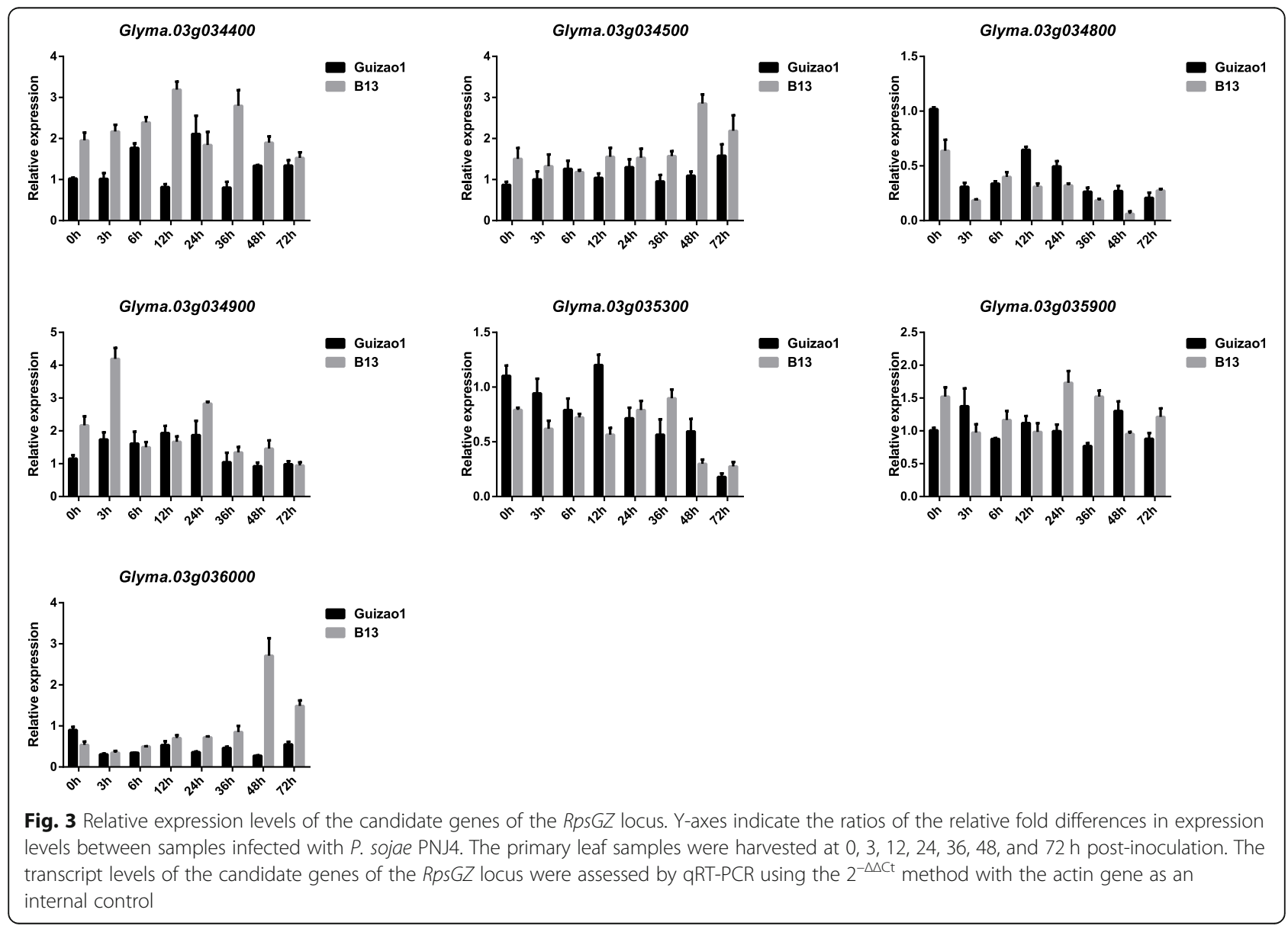


analyses indicated that resistance to $P$. sojae PNJ4 in Guizao1 was controlled by a single locus.

To more finely map the PRR resistance locus, RpsGZ was mapped in an RIL population based on genotyping through resequencing, resulting in the integration of 54, 002 SNPs into 3748 recombination bin units. These markers were then employed to construct a high-density bin linkage map with an average distance of $0.81 \mathrm{cM}$ between adjacent markers [56]. The map exhibited welldistributed linkage distances and a higher resolution than the conventional map, and gene/QTL mapping was thus more accurate and reliable. The position of RpsGZ was refined through fine mapping to a $367,371 \mathrm{bp}$ interval between 4,003,401 and 4,370,772 bp on chromosome 3 , which was the region rich in Rps genes.

Previous studies have identified 17 known Rps genes (alleles) and mapped them to chromosome 3 before RpsGZ, including five alleles of Rps1 (Rps1a, 1b, 1c, 1d, $1 \mathrm{k}$ ) [23, 24, 38, 57, 58], Rps7 [23], Rps9 [29], Rps Yu 25 [25], an Rps gene in Waseshiroge [26], RpsYD29 [27], an Rps gene in E00003 soybean within the Rps1 $k$ interval [30], RpsHC18 [10], RpsQ [13], RpsHN [14], RpsX [9], RpsWY [31], and RpsUN1 [28]. Nevertheless, the positional relationships of these Rps genes had not been confirmed, and some of the mapping intervals for these Rps genes overlapped. Therefore, whether these genes were allelic or located at a new locus needed to be confirmed.
In the present study, RpsGZ was found to be a distinct gene from the Rps 1 alleles because five varieties carrying Rps1 ( $1 a, 1 b, 1 c, 1 d$ and $1 k$ ) were PRR susceptible to $P$. sojae PNJ4, although the candidate region of RpsGZ partly overlapped with the region of Rps1. The Wayao cultivar (RpsWY) was susceptible to P. sojae PNJ4, Guizao1 was resistant to P. sojae PNJ4 [31], and these two mapping parents exhibited different resistance reactions, suggesting that RpsGZ may be different from RpsWY. Compared with the nucleotide positions of the Rps genes mapped to chromosome 3 (Table 4) according to the Glyma 2.0 soybean gene annotation database (http://soybase.org/), the positional information for RpsGZ suggested that RpsGZ was distinct from 9 known Rps genes, including Rps1a, Rps1b, Rps1c, Rps1d, Rps9, RpsQ, RpsX, RpsYu25 and RpsHC18.

In addition, Rps 7 was mapped to a $14,483,755$ bp genomic region $(3,931,955-18,415,710 \mathrm{bp})$ flanked by the SSR markers Satt009 and Satt125 [23]. RpsUN1 was localized to the region between 4,020,587 and 4,171,402 bp, flanked by two SSR markers, BARCSOYSSR_03 0233 and BARCSOYSSR_03_0246, based on the Glyma 2.0 soybean gene annotation database of the Williams 82 genome sequence [28]. Among the regions of four other known Rps genes according to the Glyma1.0 annotations, the Waseshiroge Rps gene was located between Satt009 and T003044871 and may reside in the

Table 4 The location of Rps genes on chromosome 3

\begin{tabular}{|c|c|c|c|c|c|c|}
\hline \multirow{2}{*}{$\frac{\text { No }}{1}$} & \multirow{2}{*}{$\begin{array}{l}\text { Rps gene } \\
\text { RpsGZ }\end{array}$} & \multicolumn{2}{|l|}{ Molecular marker interval } & \multicolumn{3}{|c|}{ Physical posistion (bp) } \\
\hline & & & & $4,003,401$ & - & $4,370,772^{a}$ \\
\hline 2 & $\operatorname{Rps} X$ & & & $2,910,913$ & - & $3,153,254^{a}$ \\
\hline 3 & Rps9 & Satt631 & Satt152 & $2,943,883$ & - & $3,366,655^{\mathrm{a}}$ \\
\hline 4 & RpsQ & BARCSOYSSR_03_0165 & InDel281 & $2,968,566$ & - & $3,087,579^{a}$ \\
\hline 5 & Rpsia & Satt159 & Satt009 & $3,197,845$ & - & $3,932,116^{a}$ \\
\hline 6 & RpsYu25 & Satt152 & Sat_186 & $3,366,405$ & - & $3,488,905^{\mathrm{a}}$ \\
\hline 7 & Rpsid & Satt152 & Sat_186 & $3,366,405$ & - & $3,488,905^{\mathrm{a}}$ \\
\hline 8 & Rps1 & Sat_186 & Satt530 & $3,488,616$ & - & $5,669,877^{\mathrm{a}}$ \\
\hline 9 & RpsYD29 & SattWM82-50 & Satt1 k4b & $3,857,715$ & - & $4,062,474^{b}$ \\
\hline 10 & Rps7 & Satt009 & Satt125 & $3,931,955$ & - & $18,415,710^{a}$ \\
\hline 11 & Rps gene in Waseshiroge & Satt009 & T003044871 & $3,910,260$ & - & $4,486,048^{b}$ \\
\hline 12 & RpsUN1 & BARCSOYSSR_03_0233 & BARCSOYSSR_03_0246 & $4,020,587$ & - & $4,171,402^{\mathrm{a}}$ \\
\hline 13 & RpsHN & SSRSOYN-25 & SSRSOYN-44 & $4,227,863$ & - & $4,506,526^{b}$ \\
\hline 14 & Rpsik & & & $4,457,810$ & - & $4,641,921^{b}$ \\
\hline 15 & $\operatorname{RpsWY}$ & & & $4,466,230$ & - & $4,502,773^{b}$ \\
\hline 16 & Rps gene in E00003 & & & $4,475,877$ & - & $4,563,799^{b}$ \\
\hline 17 & RpsHC18 & BARCSOYSSR_03_0265 & BARCSOYSSR_03_0272 & $4,446,594$ & - & $4,611,282^{a}$ \\
\hline 18 & Rpsib & Satt530 & Satt584 & $5,669,877$ & - & $9,228,144^{a}$ \\
\hline 19 & Rpsic & Satt530 & Satt584 & $5,669,877$ & - & $9,228,144^{\mathrm{a}}$ \\
\hline
\end{tabular}

a:the nucleotide positions of the markers were determined through a BLAST search in the Glyma 2.0 soybean gene annotation database (http://soybase.org/); b:the nucleotide positions of the markers were determined according to the Glyma 1.0 soybean gene annotation database (http://soybase.or 
nucleotide region between $3,910,260$ and 4,486,048 bp of the Williams 82 genome [26]. The Rps gene in cv. E00003 was positioned within the interval of $4,475,877$ to $4,563,799 \mathrm{bp}$ [30]. RpsHN was mapped to a $278.7 \mathrm{~kb}$ genomic region flanked by the SSR markers SSRSOYN25 and SSRSOYN-44 and may reside at nucleotide position 4,227,863 and 4,506,526 bp [14]. RpsYD29 was flanked by the markers SattWM82-50 and Satt1 k4b, which were located at nucleotide positions $3,857,715$ and 4,062,474 bp [27]. RpsGZ was also located in a region between 4,022,530 and 4,483,231 bp in GlymaWm82.a1.v1. Therefore, RpsGZ and the Rps7, RpsHN, RpsUN1, RpsYD29, and Rps genes from Waseshiroge and E00003 may be tightly linked genes, different alleles of the same gene, or identical alleles of the same gene. However, further confirmation is needed. Moreover, if the sources of resistance mentioned above carry different resistance genes, a pyramiding effect of different resistance genes may increase the resistance of soybean cultivars to $P$. sojae.

The NBS-LRR genes are the extremely large family of plant disease resistance genes [59], and the local tandem duplication of NBS genes has created many homogenous clustered loci in each legume genome studied to date [60]. Meziadi et al. suggested that the NBS-LRR proteins are encoded by one of the largest and most variable multigene families and are often organized into complex clusters of tightly linked genes in plants [61]. In soybean, 319 putative NBS-LRR genes and 175 disease resistance QTLs have been found, among which 36 NBS-LRR genes are clustered on chromosome 3 , and most of the NBS-LRR genes are located at the front end of chromosome 3 [62]. The 17 identified $R p s$ genes were all mapped to regions between 2,943,883 and 9,228,144 bp on chromosome 3. In addition, some genes or QTLs for resistance to abiotic or biotic stresses in soybean have been mapped near the region of RpsGZ on chromosome 3. For instance, the QTL Raso1 for major foxglove aphid resistance was mapped to a 63-kb interval containing an NBS-LRR-type R-like gene and two other genes in the Williams 82 sequence assembly [63]. A minor foxglove aphid resistance QTL in PI 366121 [64], two soybean sudden death syndrome resistance QTLs, di1 [65, 66] (also known as $q R f s 6$ [67]) and SDS14-1 [68], and the major QTLs or dominant loci underlying salt tolerance in the soybean cultivars Tiefeng8 and Jidou12 $[69,70]$ might be clustered in the region as Rps resistance genes. Among the 19 genes in the region close to RpsGZ detected in this study, five gene candidates were NB-ARC domain and leucine-rich repeat-containing (NBS-LRR) genes, which are a typical type of so-called R-genes. NBS-LRR-type genes have been implicated in the resistance of Rps1 k [38]. qRT-PCR analysis showed differential expression patterns of the NBS-LRR-type gene
Glyma.03 g05300 between Guizao1 and BRSMG68, and this gene may be involved in defence mechanisms against disease.

\section{Conclusions}

We identified and finely mapped a novel Rps locus (RpsGZ) that can confer resistance to P. sojae PNJ4 and PNJ1 on chromosome 3, which could be used for the breeding of Phytophthora-resistant cultivars. The R-like gene Glyma.03 g05300 may be involved in diseasedefence mechanisms. This study provides information regarding the genetic location of the Rps resistance locus, which is useful for breeders to apply markerassisted selection (MAS) in soybean breeding programmes to achieve resistance to $P$. sojae.

\section{Methods \\ Plant materials}

The mapping populations of $228 \mathrm{~F}_{8: 11}$ recombinant inbred lines (RILs) derived from a Guizaol $\left(\mathrm{P}_{1}\right.$, PRR resistance $) \times$ BRSMG68 $\quad\left(\mathrm{P}_{2}, \quad\right.$ PRR susceptible $)$ cross were developed via the single-seed descent method [71]. The soybean cv. Guizaol was developed in Guangxi, China. BRSMG68 was introduced from Brazil. Both cv. Guizao1 and BRSMG68 were obtained from the Guangdong Subcenter of the National Center for Soybean Improvement, South China Agricultural University.

To determine which Rps gene or Rps gene combination was present in Guizaol, a differential set of 13 cultivars/genotypes was used. Each cultivar/genotype carried a single known Rps gene: Harlon (Rps1a), Harosoy13XX (Rps1b), Williams79 (Rps1c), PI103091 (Rps1d), Williams82 (Rps1 k), L76-988 (Rps2), L83-570 (Rps3a), PRX146-36 (Rps3b), PRX145-48 (Rps3c), L85-2352 (Rps4), L85-3059 (Rps5), Harosoy62XX (Rps6) and Harosoy (Rps7). The variety Williams (no known Rps gene) was used as a susceptible variety to verify successful inoculation. All the different hosts used for PRR identification were kindly provided by the National Center for Soybean Improvement, Nanjing Agricultural University.

\section{P. sojae isolates}

Six P. sojae isolates (PNJ4, Pm14, Pm28, PNJ1, PNJ3, P6497), which were provided by Prof. Yuanchao Wang and Han Xing at Nanjing Agricultural University were preserved on V8 juice agar medium $(10 \%$ V8 vegetable juice, $0.02 \% \mathrm{CaCO}_{3}$ and 1.0\% Bacto-agar) $[12,14]$. These $P$. sojae isolates were used in the phenotype test of disease resistance to PRR among Guizao1 and BRSMG68 and 13 different cultivars/genotypes. The $P$. sojae PNJ4 strain (virulence formula is $1 a, 1 b, 1 c, 1 d, 1 k, 2,3 b, 3 c$, 4 , 6) was used to evaluate the RIL population of Guizao1 × BRSMG68. 


\section{Evaluation of genetic materials for Phytophthora resistance}

The method of injured hypocotyl inoculation with slight modification was utilized for disease evaluation in this experiment $[12,25]$. For inoculation with $P$. sojae, 15 plants of each host used for PRR identification and each line of the RIL population and the parents were planted in 11.8 -cm-diameter plastic pots filled with vermiculite and kept in an illumination incubator $\left(26 / 22^{\circ} \mathrm{C}\right.$ day/ night temperature, $75 \%$ relative humidity, $12 \mathrm{~h}$ light $/ 12 \mathrm{~h}$ dark photoperiod and average light intensity of $\sim 10,000$ Lx).

Seven days after sowing, the seedlings were inoculated. A thinner uniform wound was cut in the soybean cotyledon under a section of $1-2 \mathrm{~cm}$ by using a single-sided blade sterilized with the outer flame of an alcohol lamp. The active edges of the colonies of the $P$. sojae isolates cultured in the incubator at $25^{\circ} \mathrm{C}$ for 5 days were cut into approximately $3 \mathrm{~mm}^{2}$ blocks and then embedded in the wound with the mycelium surface inward. After inoculation, the seedlings were placed on a culture shelf surrounded by plastic film; the moisture content was maintained at $90 \%$ relative humidity and the temperature at $25^{\circ} \mathrm{C}$ for $24 \mathrm{~h}$, and the plants were sprayed with sterile water, then transferred to the illumination incubator $\left(26 / 22^{\circ} \mathrm{C}\right.$ day/night temperature, $75 \%$ relative humidity, $12 \mathrm{~h}$ light $/ 12 \mathrm{~h}$ dark photoperiod and average light intensity of $\sim 10,000 \mathrm{Lx})$. The evaluation test was set up with three biological experiments. To test the phenotypes of the RIL population inoculated with the PNJ4 isolate, Williams (rps gene) was used as the susceptible cultivar to indicate successful inoculation. All the experiments were performed in 2017 and 2018 at South China Agricultural University.

The reactions of all materials were recorded as the percentage of dead seedlings at 5 days after inoculation. Cultivars for PRR identification were considered resistant if all the seedlings were alive with no expanded lesions. Cultivars were considered susceptible if all the seedlings were dead. The RIL families with 70-100\% dead seedlings were considered to be homozygous susceptible (S), while the RIL families with $0-30 \%$ dead seedlings were considered to be resistant (R), and the RIL families with 31-69\% dead seedlings were considered to be heterozygous resistant (Rs) [12].

\section{Data analysis and candidate gene prediction}

A goodness-of-fit to the Mendelian segregation ratio was calculated via Chi-square $\left(\mathrm{X}^{2}\right)$ analysis to examine the segregation patterns of the phenotypes.

The linkage map used in this study was constructed previously by the Guangdong Subcenter of National Center for Soybean Improvement, South China Agricultural University. This map included 3748 bins and was $3031.9 \mathrm{cM}$ in length, with an average distance of $0.81 \mathrm{cM}$ between adjacent markers on 20 chromosomes [56]. Composite interval mapping (CIM) was used to detect gene/QTLassociated PRR resistance using phenotypic data via in WinQTLCart 2.5 software (http://statgen.ncsu.edu/ qtlcart/WQTLCart.htm). The LOD thresholds for gene/ QTL significance were determined by a test (1000 replications) with a genome-wide scope at the $5 \%$ level of significance. Gene mapping results were compared to SoyBase, and the predicted genes in the target regions were analysed according to the annotation of the soybean reference genome (Wm82.a2.v1) in Soybase (http://www.soybase. $\operatorname{org} /)$. The functional predictions of genes were manually confirmed by using the BLAST function in the NCBI (http://www.ebi.ac.uk/Tools/sss/ncbiblast/) and TAIR protein datasets (http://www.arabidopsis.org/).

\section{Expression analysis of candidate genes}

Guizao1 and BRSMG68 seedlings were cultivated for 7 days and inoculated with $P$. sojae PNJ4, then transferred to the illumination incubator at $25^{\circ} \mathrm{C}, 75 \%$ relative humidity and a $12 \mathrm{~h}$ light $/ 12 \mathrm{~h}$ dark photoperiod. Total RNA was isolated from the primary leaves at $0,3,12,24$, 36,48 , and $72 \mathrm{~h}$ postinoculation. Total RNA was extracted from the plants using TRIzol reagent (Invitrogen, USA) according to the manufacturer's instructions, and $1 \mu \mathrm{g}$ of DNase-treated RNA was subjected to reverse transcription using a PrimeScript RT Reagent kit with gDNA Eraser (Takara, Japan).

Candidate genes in the target region were predicted using the Williams 82 soybean reference genome GlymaWm82.a2.v1 (http://soybase.org). qRT-PCR was conducted to obtain the expression profiles of candidate genes using primers designed with Primer Premier 5.0. The housekeeping gene Actin was used as a control. The specific primers for each gene are listed in additional file Table S3.

qRT-PCR was performed with a CFX96 Real-Time PCR Detection System (Bio-Rad, USA) using a KAPA SYBR ${ }^{\circ}$ FAST qPCR Kit (Kapa Biosystems). All reactions were carried out in $20-\mu \mathrm{l}$ volumes containing $1 \mu \mathrm{l} \mathrm{cDNA}$ as a template. The thermal cycling conditions were as follows: $95^{\circ} \mathrm{C}$ for $3 \mathrm{~min}$, followed by 40 cycles of $95^{\circ} \mathrm{C}$ for $10 \mathrm{~s}, 55.0$ $63.3^{\circ} \mathrm{C}$ (depending on the gene) for $10 \mathrm{~s}$ and $72{ }^{\circ} \mathrm{C}$ for $30 \mathrm{~s}$. Three independent biological repeats were performed to ensure accurate statistical analysis. The qRT-PCR data were evaluated using the $2^{-\Delta \Delta C t}$ method [72].

\section{Supplementary information}

Supplementary information accompanies this paper at https://doi.org/10. 1186/s12864-020-6668-z.

Additional file 1: Table S1. Gene ontology (GO) enrichment analysis of the candidate genes. Table S2. The biological process and molecular 
function ontology of the candidate genes. Table S3. Primers of the candidate genes for real-time PCR.

Additional file 2: Figure S1. Twenty linkage groups of the soybean high-density genetic map. A high-density bin linkage map was constructed, covering $3032 \mathrm{cM}$, with an average distance of $0.81 \mathrm{cM}$ between adjacent bins. The bin markers and their locations are shown on the right and left sides, respectively.

Additional file 3: Figure S2. Gene ontology $(\mathrm{GO})$ enrichment analysis of the candidate genes of the RpsGZ locus. AgriGO (http://bioinfo.cau. edu.cn/agriGO/) was used to analyse the candidate genes of the RpsGZ locus, and significantly enriched GO categories under molecular functions are shown in orange and yellow boxes.

\section{Abbreviations}

bp: Base pair; CIM: Composite interval mapping; CM: Centimorgan; cv.: Cultivar; GO: Gene ontology; MAS: Molecular-assisted selection; NGS: Next-generation sequencing; PPR: Phytophthora root rot; $P$. sojae: Phytophthora sojae; RIL: Recombinant inbred line; SNP: Single nucleotide polymorphism; LOD: Log-likelihood

\section{Acknowledgements}

We thank Yuanchao Wang and Han Xing (Nanjing Agricultural University, Nanjing, PR China) for their kindly supplying the P. sojae PNJ4 strain and other strains.

\section{Authors' contributions}

$\mathrm{BJ}$ and $\mathrm{YC}$ performed the experiments and analysed the data. $\mathrm{YC}$ and $\mathrm{ML}$ generated the RILs population. ZC provided guidance on the molecular analysis. ZJ, RM and YY conducted phenotypic screenings. QX analysed the data of genome-wide sequencing to produce the final linkage and bin maps. $\mathrm{HN}$ planned the research, supervised the project and prepared the manuscript. All authors read and approved the final manuscript.

\section{Authors' information}

Bingzhi Jiang and Yanbo Cheng contributed equally to this work.

\section{Funding}

This work was supported by the National Key R\&D Program of China (2018YFD0201006); the China Agricultural Research System (CARS-04-PS09); the Guangdong Agricultural Research System (2019KJ136) and a project of the Key Laboratory of Plant Molecular Breeding of Guangdong Province (GPKLPMB201905). The funding bodies had no role in the study design, data collection, analysis and interpretation, decision to publish, or writing of the manuscript.

\section{Availability of data and materials}

The datasets supporting the results of this study are included in the manuscript. Soybean seeds are available from the Guangdong Subcenter of the National Center for Soybean Improvement, PR China.

\section{Ethics approval and consent to participate}

Not applicable.

\section{Consent for publication}

Not applicable.

\section{Competing interests}

The authors declare that they have no competing interests.

\section{Author details}

'The State Key Laboratory for Conservation and Utilization of Subtropical Agro-bioresources, South China Agricultural University, Guangzhou, Guangdong 510642, People's Republic of China. ${ }^{2}$ The Key Laboratory of Plant Molecular Breeding of Guangdong Province, College of Agriculture, South China Agricultural University, Guangzhou, Guangdong 510642, People's Republic of China. ${ }^{3}$ Guangdong Provincial Key Laboratory of Crops Genetics and Improvement, Crops Research Institute, Guangdong Academy of Agricultural Sciences, Guangzhou 510640, People's Republic of China. ${ }^{4}$ Beijing Genomics Institute (BGI) Education Center, University of Chinese Academy of Sciences, Shenzhen 518083, People's Republic of China.
Received: 26 February 2020 Accepted: 12 March 2020

Published online: 03 April 2020

\section{References}

1. Tyler BM. Phytophthora sojae: root rot pathogen of soybean and model oomycete. Mol Plant Pathol. 2010;8(1):1-8

2. Sugimoto T, Kato M, Yoshida S, Matsumoto I, Kobayashi T, Kaga A, Hajika M, Yamamoto R, Watanabe K, Aino M. Pathogenic diversity of Phytophthora sojae and breeding strategies to develop Phytophthora-resistant soybeans. Breeeding Sci. 2012;61(5):511-22.

3. Dorrance AE, Mcclure SA, Martin SKS. Effect of partial resistance on Phytophthora stem rot incidence and yield of soybean in Ohio. Plant Dis. 2003:87(3):308-12

4. Zhang JQ, Xia CJ, Duan CX, Sun SL, Wang XM, Wu XF, Zhu ZD. Identification and candidate gene analysis of a novel phytophthora resistance gene Rps 10 in a Chinese soybean cultivar. PLoS One. 2013;8(7):e69799.

5. Ortega MA, Dorrance AE. Microsporogenesis of Rps8/rps8 heterozygous soybean lines. Euphytica. 2011;181(1):77.

6. Burnham KD, Dorrance AE, Francis DM, Fioritto RJ, Martin SKS. Rps8, a new locus in soybean for resistance to Phytophthora sojae. Crop Sci. 2003;43(1): $101-5$.

7. Fan AY, Wang XM, Fang XP, Xiao-Fei WU, Zhen-Dong AZ. Molecular identification of Phytophthora resistance gene in soybean cultivar Yudou25. Acta Agron Sin. 2009;35(10):1844-50.

8. Yan YH, Ming WX, Fei WX, Nong XY, Dong ZZ. Molecular mapping of Phytophthora resistance gene in soybean cultivar Zaoshu18. J Plant Genet Res. 2010;11(2):213-7.

9. Zhong C, Li Y, Sun S, Duan C, Zhu Z. Genetic mapping and molecular characterization of a broad-spectrum Phytophthora sojae resistance gene in Chinese soybean. Int J Mol Sci. 2019;20(8):1809.

10. Zhong C, Sun S, Li Y, Duan C, Zhu Z. Next-generation sequencing to identify candidate genes and develop diagnostic markers for a novel Phytophthora resistance gene, RpsHC18, in soybean. Theor Appl Genet. 2018;131(3):525-38.

11. Zhong C, Sun S, Yao L, Ding J, Duan C, Zhu Z. Fine mapping and identification of a novel Phytophthora root rot resistance locus RpsZS18 on chromosome 2 in soybean. Front Plant Sci. 2018;9:44.

12. Sandhu D, Gao HY, Cianzio S, Bhattacharyya MK. Deletion of a disease resistance nucleotide-binding-site leucine-rich-repeat-like sequence is associated with the loss of the Phytophthora resistance gene Rps 4 in soybean. Genetics. 2004;168:2157-67.

13. Li Y, Sun S, Zhong C, Wang X, Wu X, Zhu Z. Genetic mapping and development of co-segregating markers of $R p s Q$, which provides resistance to Phytophthora sojae in soybean. Theor Appl Genet. 2017;130(6):1223-33.

14. Niu J, Guo N, Sun J, Li L, Cao Y, Li S, Huang J, Zhao J, Zhao T, Xing H. Fine mapping of a resistance gene RpsHN that controls Phytophthora sojae using recombinant inbred lines and secondary populations. Front Plant Sci. 2017; 8:538.

15. Qin J, Song Q, Shi A, Li S, Zhang M, Zhang B. Genome-wide association mapping of resistance to Phytophthora sojae in a soybean [Glycine max (L.) Merr.] germplasm panel from maturity groups IV and V. Plos One. 2017; 12(9):e184613.

16. Sahoo DK, Abeysekara NS, Cianzio SR, Robertson AE, Bhattacharyya MK. A novel Phytophthora sojae resistance Rps 12 gene mapped to a genomic region that contains several Rps genes. PLoS One. 2017;12(1):e169950.

17. Li L, Lin F, Wang W, Ping J, Fitzgerald JC, Zhao M, Li S, Sun L, Cai C, Ma J. Fine mapping and candidate gene analysis of two loci conferring resistance to Phytophthora sojae in soybean. Theor Appl Genet. 2016;129(12):2379-86.

18. Ping J, Fitzgerald JC, Zhang C, Lin F, Bai Y, Wang D, Aggarwal R, Rehman M, Crasta O, Ma J. Identification and molecular mapping of Rps11, a novel gene conferring resistance to Phytophthora sojae in soybean. Theor Appl Genet. 2016;129(2):445-51.

19. Sun J, Li L, Zhao J, Huang J, Yan Q, Xing H, Guo N. Genetic analysis and fine mapping of Rps JS, a novel resistance gene to Phytophthora sojae in soybean [Glycine max (L.) Merr.]. Theor Appl Genet. 2014;127(4):913-9.

20. Schmitthenner AF. Phytophthora rot of soybean. Plant Health Progress. 2000; 1(1):13 Available: http://www.plantmanagementnetwork.org/pub/php/ management/phytophthora/.

21. Schmitthenner AF. Problems and progress in control of Phytophthora root rot of soybean. Plant Dis. 1985;69(4):362-8. 
22. Demirbas A, Rector BG, Lohnes DG, Fioritto RJ, Graef GL, Cregan PB, Shoemaker RC, Specht JE. Simple sequence repeat markers linked to the soybean genes for Phytophthora resistance. Crop Sci. 2001;41(4):1220-7.

23. Weng C, Yu K, Anderson TR, Poysa V. Mapping genes conferring resistance to Phytophthora root rot of soybean, Rps1a and Rps7. J Heredity. 2001;92(5): 442-6.

24. Gao H, Narayanan NL, Bhattacharyya MK. Two classes of highly similar coiled coil-nucleotide binding-leucine rich repeat genes isolated from the Rps 1-k locus encode Phytophthora resistance in soybean. Mol Plant-Microbe Interact. 2005;18(10):1035-45.

25. Sun S, Wu XL, Zhao JM, Wang YC, Tang QH, Yu DY, Gai JY, Xing H. Characterization and mapping of RpsYu25, a novel resistance gene to Phytophthora sojae. Plant Breed. 2011;130(2):139-43.

26. Sugimoto T, Yoshida S, Kaga A, Hajika M, Watanabe K, Aino M, Tatsuda K, Yamamoto R, Matoh T, Walker DR, et al. Genetic analysis and identification of DNA markers linked to a novel Phytophthora sojae resistance gene in the Japanese soybean cultivar Waseshiroge. Euphytica. 2011;182(1):133-45.

27. Zhang J, Xia C, Wang X, Duan C, Sun S, Wu X, Zhu Z. Genetic characterization and fine mapping of the novel Phytophthora resistance gene in a Chinese soybean cultivar. Theor Appl Genet. 2013;126(6):1555-61.

28. Lin F, Ping J, Johnson A, Zhang B, Abney TS, Hughes TJ. Molecular mapping of two genes conferring resistance to Phytophthora sojae in a soybean landrace PI 567139B. Theor Appl Genet. 2013;126(8):2177-85.

29. Wu XL, Zhang BQ, Sun S, Zhao JM, Yang F, Guo N, Gai JY, Xing H. Identification, genetic analysis and mapping of resistance to Phytophthora sojae of Pm28 in soybean. Agric Sci China. 2011;10(10):1506-11.

30. Zhang ZN, Hao JJ, Yuan JZ, Song QJ, Hyten DL, Cregan PB, Zhang GR, Gu $\mathrm{CH}$, Ming L, Wang DC. Phytophthora root rot resistance in soybean E00003. Crop Sci. 2014:54(2):492-9.

31. Cheng Y, Ma Q, Ren H, Xia Q, Song E, Tan Z, Li S, Zhang G, Nian H. Fine mapping of a Phytophthora-resistance gene RpsWY in soybean (Glycine max L.) by high-throughput genome-wide sequencing. Theor Appl Genet. 2017; 130(5):1041-51.

32. Gordon SG, Dorrance AE, Martin SKS. 8 maps to a resistance gene rich region on soybean molecular linkage group F. Crop Sci. 2006;46(1):168-73.

33. Yu AL, Xu PF, Wang JS, Zhang SZ, Wu JJ, Li WB, Chen WY, Li NH, Fan SJ, Wang $X$. Genetic analysis and SSR mapping of gene resistance to Phytophthora sojae race 1 in soybean cv Suinong 10. Chin J Oil Crop Sci. 2010;32(4):462-6.

34. Diers BW, Mansur L, Imsande J, Shoemaker RC. Mapping Phytophthora resistance loci in soybean with restriction fragment length polymorphism markers. Crop Sci. 1992;32(2):377-83.

35. Kilen TC. Relationships between Rps2 and other genes controlling resistance to Phytophthora rot in soybean. Crop Sci. 1986;26(4):711-2.

36. Wu XL, Zhou B, Sun S, Zhao JM, Chen SY, Gai JY, Xing H. Genetic analysis and mapping of resistance to Phytophthora sojae of Pm14 in soybean. Sci Agric Sin. 2011:44(3):456-60.

37. Zhu Z, Huo Y, Wang X, Huang J, Wu X. Molecular identification of a novel phytophthora resistance gene in soybean. Acta Agron Sin. 2007;33(1):154-7.

38. Gao H, Bhattacharyya MK. The soybean-Phytophthora resistance locus Rps 1k encompasses coiled coil-nucleotide binding-leucine rich repeat-like genes and repetitive sequences. BMC Plant Biol. 2008;8(1):29.

39. Elshire RJ, Glaubitz JC, Sun Q, Poland JA, Kawamoto K, Buckler ES, Mitchell SE. A robust, simple genotyping-by-sequencing (GBS) approach for high diversity species. PLoS One. 2011;6(5):e19379.

40. Sun X, Liu D, Zhang X, Li W, Liu H, Hong W, Jiang C, Guan N, Ma C, Zeng H, et al. SLAF-seq: an efficient method of large-scale de novo SNP discovery and genotyping using high-throughput sequencing. PLoS One. 2013;8(3):e58700.

41. Miller MR, Dunham JP, Amores A, Cresko WA, Johnson EA. Rapid and costeffective polymorphism identification and genotyping using restriction site associated DNA (RAD) markers. Genome Res. 2007;17(2):240-8.

42. Wang S, Meyer E, McKay JK, Matz MV. 2b-RAD: a simple and flexible method for genome-wide genotyping. Nat Methods. 2012;9(8):808-10

43. Zhao X, Han Y, Li Y, Liu D, Sun M, Zhao Y, Lv C, Li D, Yang Z, Huang L, et al. Loci and candidate gene identification for resistance to Sclerotinia sclerotiorum in soybean (Glycine max L. Merr.) via association and linkage maps. Plant J. 2015;82(2):245-55.

44. Li G, Wang Y, Chen M, Edae E, Poland J, Akhunov E, Chao S, Bai G, Carver $B F$, Yan L. Precisely mapping a major gene conferring resistance to hessian fly in bread wheat using genotyping-by-sequencing. BMC Genomics. 2015; 16(1):108.
45. Ma GJ, Markell SG, Song QJ, Qi LL. Genotyping-by-sequencing targeting of a novel downy mildew resistance gene $\mathrm{Pl}_{20}$ from wild Helianthus argophyllus for sunflower (Helianthus annuus L.). Theor Appl Genet. 2017;130(7):1519-29.

46. Ma GJ, Song QJ, Markell SG, Qi LL. High-throughput genotyping-bysequencing facilitates molecular tagging of a novel rust resistance gene, $\mathrm{R}_{15}$, in sunflower (Helianthus annuus L.). Theor Appl Genet. 2018;131(7): 1423-32.

47. Xu X, Chao J, Cheng X, Wang R, Sun B, Wang H, Luo S, Xu X, Wu T, Li Y. Mapping of a novel race specific resistance gene to phytophthora root rot of pepper (capsicum annuum) using bulked segre. PLoS One. 2016;11(3): e151401.

48. Du Z, Zhou X, Ling Y, Zhang Z, Su Z. AgriGO: a GO analysis toolkit for the agricultural community. Nucleic Acids Res. 2010;38:64-70.

49. Tian T, Liu Y, Yan H, You Q, Yi X, Du Z, Xu W, Su Z. AgriGO v2.0: a GO analysis toolkit for the agricultural community, 2017 update. Nucleic Acids Res. 2017:45:122-9.

50. Scott C. Peck. Analysis of protein phosphorylation: methods and strategies for studying kinases and substrates. Plant J. 2006;45(4):512-22.

51. Kyle DE, Nickell CD, Nelson RL, Pedersen WL. Response of soybean accessions from provinces in southern China to Phytophthora sojae. Plant Dis. 2007:82(5):555-9.

52. Lohnes DG, Nickell CD, Schmitthenner AF. Origin of soybean alleles for Phytophthora resistance in China. Crop Sci. 1996;36(6):1689-92.

53. Huang J, Guo N, Li Y, Sun J, Hu G, Zhang H, Li Y, Zhang X, Zhao J, Xing H, et al. Phenotypic evaluation and genetic dissection of resistance to Phytophthora sojae in the Chinese soybean mini core collection. BMC Genet 2016;17(1):85

54. Jiang C, Sugano S, Kaga A, Lee SS, Sugimoto T, Takahashi M, Ishimoto M. Evaluation of resistance to Phytophthora sojae in soybean mini core collections using an improved assay system. Phytopathology. 2017;107(2): 216-23

55. Zhang J, Sun S, Wang G, Duan C, Wang X, Wu X, Zhu Z. Characterization of Phytophthora resistance in soybean cultivars/lines bred in Henan province. Euphytica. 2014;196(3):375-84.

56. Jiang B, Li M, Cheng Y, Cai Z, Ma Q, Jiang Z, Ma R, Xia Q, Zhang G, Nian H. Genetic mapping of powdery mildew resistance genes in soybean by highthroughput genome-wide sequencing. Theor Appl Genet. 2019;132(6):1833-45.

57. Bernard RL, Smith PE, Kaufmann MJ, Schmitthenner AF. Inheritance of resistance to Phytophthora root and stem rot in the soybean. Agron J. 1957; 49(7):391.

58. Sugimoto T, Yoshida S, Watanabe K, Aino M, Kanto T, Maekawa K, Irie K. Identification of SSR markers linked to the Phytophthora resistance gene Rps 1-d in soybean. Plant Breed. 2008;127(2):154-9.

59. Shao Z, Xue J, Wu P, Zhang Y, Wu Y, Hang Y, Wang B, Chen J. Large-scale analyses of angiosperm nucleotide-binding site-leucine-rich repeat genes reveal three anciently diverged classes with distinct evolutionary patterns. Plant Physiol. 2016;170(4):2095-109.

60. Shao Z, Zhang Y, Hang Y, Xue J, Zhou G, Wu P, Wu X, Wu X, Wang Q, Wang $B$, et al. Long-term evolution of nucleotide-binding site-leucine-rich repeat genes: understanding gained from and beyond the legume family. Plant Physiol. 2014;166(1):217-34.

61. Meziadi C, Richard MMS, Derquennes A, Thareau V, Blanchet S, Gratias A, Pflieger S, Geffroy V. Development of molecular markers linked to disease resistance genes in common bean based on whole genome sequence. Plant Sci. 2016:242:351-7.

62. Kang Y, Kim K, Shim S, Yoon M, Sun S, Kim M, Van K, Lee S. Genome-wide mapping of NBS-LRR genes and their association with disease resistance in soybean. BMC Plant Biol. 2012;12(1):139.

63. Ohnishi S, Miyake N, Takeuchi T, Kousaka F, Hiura S, Kanehira O, Saito M, Sayama T, Higashi A, Ishimoto M, et al. Fine mapping of foxglove aphid (Aulacorthum solani) resistance gene Rasol in soybean and its effect on tolerance to soybean dwarf virus transmitted by foxglove aphid. Breeding Sci. 2012;61(5):618-24.

64. Lee JS, Yoo M, Jung JK, Bilyeu KD, Lee J, Kang S. Detection of novel QTLS for foxglove aphid resistance in soybean. Theor Appl Genet. 2015;128(8): 1481-8.

65. Chang SJC, Doubler TW, Kilo V, Suttner R, Klein J, Schmidt ME, Gibson PT, Lightfoot DA. Two additional loci underlying durable field resistance to soybean sudden death syndrome (SDS). Crop Sci. 1996;36(6):1684-8.

66. Njiti VN, Meksem K, labal MJ, Johnson JE, Kassem MA, Zobrist KF, Kilo W, Lightfoot DA. Common loci underlie field resistance to soybean sudden 
death syndrome in Forrest, pyramid, Essex, and Douglas. Theor Appl Genet. 2002;104(2-3):294-300

67. Luckew AS, Leandro LF, Bhattacharyya MK, Nordman DJ, Lightfoot DA, Cianzio SR. Usefulness of 10 genomic regions in soybean associated with sudden death syndrome resistance. Theor Appl Genet. 2013;126(9):2391403.

68. Bao Y, Kurle JE, Anderson G, Young ND. Association mapping and genomic prediction for resistance to sudden death syndrome in early maturing soybean germplasm. Mol Breeding. 2015;35(6):128.

69. Guan R, Chen J, Jiang J, Liu G, Liu Y, Tian L, Yu L, Chang R, Qiu L. Mapping and validation of a dominant salt tolerance gene in the cultivated soybean (Glycine max) variety Tiefeng 8. Crop J. 2014;2(6):358-65.

70. Shi X, Yan L, Yang C, Yan W, Moseley DO, Wang T, Liu B, Di R, Chen P, Zhang M. Identification of a major quantitative trait locus underlying salt tolerance in 'Jidou 12' soybean cultivar. BMC Res Notes. 2018;11(1):95.

71. Brim CA. A modified pedigree method of selection in soybeans. Crop Sci. 1966;6(2):220

72. Livak KJ, Schmittgen TD. Analysis of relative gene expression data using real-time quantitative PCR and the 2- $\Delta \Delta C \mathrm{Ct}$ method. Methods. 2001;25:4028.

\section{Publisher's Note}

Springer Nature remains neutral with regard to jurisdictional claims in published maps and institutional affiliations.

- fast, convenient online submission

- thorough peer review by experienced researchers in your field

- rapid publication on acceptance

- support for research data, including large and complex data types

- gold Open Access which fosters wider collaboration and increased citations

- maximum visibility for your research: over $100 \mathrm{M}$ website views per year

At $\mathrm{BMC}$, research is always in progress. 